\title{
Adult mesenchymal stem cells and their possibilities for Dentistry: what to expect?
}

\author{
José Ricardo Muniz Ferreira'1 ${ }^{1}$ Anna Paula Greck²
}

DOI: https://doi.org/10.1590/2177-6709.25.3.085-092.sar

Introduction: Stem cells obtained from the pulp of human deciduous teeth are highly proliferative and plastic multipotent cells, which makes them a relevant model of stem cells, applied in several biomedical areas, with different purposes. Objective: Based on a brief review of the literature, the present work intends to present from conceptual aspects about stem cells, classifications, potential (in vitro and in vivo) applications in dental practice, cell culture, cryopreservation and its importance, ethical and regulatory aspects, as well as the role of the dental surgeon as the endorser responsible for the entire clinical stage that involves the process of collecting stem cells obtained from dental pulps for cryopreservation, with a view to using them under appropriate conditions, in accordance with scientifically proven and justified good laboratory and clinical practices.

Keywords: Mesenchymal stem cells. Regenerative dentistry. Cell therapy. Tissue bioengineering. Cryopreservation.

Introdução: As células-tronco obtidas a partir da polpa de dentes decíduos humanos são células multipotentes altamente proliferativas e plásticas, o que as torna um modelo relevante de células-tronco, aplicado em diversas áreas biomédicas, com diferentes propósitos. Objetivo: A partir de uma breve revisão da literatura, o presente trabalho pretende apresentar desde aspectos conceituais acerca das células-tronco, classificações, potenciais aplicações (in vitro e in vivo) na prática odontológica, cultivo celular, criopreservação e sua importância, aspectos éticos e regulatórios, bem como o papel do cirurgião-dentista como homologador responsável por toda a etapa clínica que envolve o processo de coleta das células-tronco obtidas a partir de polpas dentais para criopreservação, com vistas ao uso em condições adequadas, em acordo com as boas práticas laboratoriais e clínicas cientificamente comprovadas e justificadas.

Palavras-chave: Células-tronco mesenquimais. Odontologia regenerativa. Terapia celular. Bioengenharia de tecido. Criopreservação.

${ }^{1}$ Instituto Militar de Engenharia (Rio de Janeiro/RJ, Brazil).

${ }^{2}$ University of Paris (Paris, France).
How to cite: Ferreira JRM, Greck AP. Adult mesenchymal stem cells and their possibilities for Dentistry: what to expect? Dental Press J Orthod. 2020 May-June;25(3):85-92.

DOI: https://doi.org/10.1590/2177-6709.25.3.085-092.sar

Submitted: May 15, 2020 - Revised and accepted: May 25, 2020

Contact address: Anna Paula Greck
E-mail: annapaula@greckodontologia.com
" The author José Ricardo Muniz is Founder and CEO of the company R-Crio Criogenia S.A. (Campinas/SP, Brazil). 


\section{INTRODUCTION}

The search for longevity associated with good quality of life has accompanied the history of humanity since the beginning of time. Over the past 50 years, we have increased our life expectancy, worldwide, by approximately 30 years. ${ }^{1}$ Much of this is due to small changes in habits and major scientific and clinical advances that have enabled the implementation of increasingly effective prevention, control and treatment measures for so-called infectious diseases. In those places where such measures have been successfully established, considering the socioeconomic and cultural aspects involved, these diseases today account for about $5 \%$ of the indices mortality. ${ }^{2}$ However, there is still much to be done, and today so-called degenerative diseases represent a major challenge to be overcome so that we can move forward with the purpose of living longer and living well.

There is no doubt about the important role played by Dentistry along this journey. After all, many of the pathologies that affect the stomatognathic system have decisive systemic consequences for the longevity-quality of life binomial to be enforced.

From the twentieth century, Cell Biology and Genetics began to contribute as diagnostic tools and therapies aimed at treating many of the ills that afflict humanity. In the 50s, it was carried out, by Edward Donnall Thomas, the first bone marrow transplant. In 1961, James Till and Ernest McCulloch pointed to the existence of hematopoietic stem cells in the bone marrow of mice, opening a perspective for understanding the mechanisms involved in these transplants. ${ }^{3}$ Between the 70s and 80s, Professor Alexander Friedenstein's team, studying mesenchymal stem cells, demonstrated the capacity for self-renewal and differentiation of these cells, attracting attention from the scientific community to the need to promote research aimed at the use, in a targeted and predictable way, of this biological material, in relation to embryonic stem cells already known previously (Fig 1).

Adult mesenchymal stem cells present themselves as an important instrument within the fields of Regenerative Medicine and Dentistry, as they are cells that, despite being nonspecific, have a great capacity for multiplication, differentiation into specialized cells and constituents of specialized tissues and with immunomodulatory competence. There are reports of a large number of places from which adult mesenchymal stem cells can be isolated, such as: bone marrow, ${ }^{4}$ adipose tissue,${ }^{5}$ musculoskeletal tissue ${ }^{6}$, labial orbicularis muscle ${ }^{7}$, dental pulp ${ }^{8}$, dermis ${ }^{9}$ and pulp of primary teeth. ${ }^{10}$

\section{STEM CELLS AND THEIR POSSIBILITIES IN RE- GENERATIVE DENTISTRY AND MEDICINE}

1. Stratification of patients: use of stem cells to recreate a specific disease in the laboratory (Alzheimer's, Autism, Parkinson, etc.) and, thus, allow a more detailed investigation of the disease, so that new treatments can be developed (Fig 2).

2. Drug development and testing: use of stem cells to generate tissues or organs of interest for the development and testing of new drugs, allowing for a local and systemic evaluation without the need for tests on animals and humans (Fig 3).

3. Generation of functional organs in the laboratory: by directing the differentiation of stem cells associated with a specific framework (previously decellularized organ), generating functional and immunologically compatible organs ${ }^{14-16}$ (Fig 4).

4. Cell therapy: by transplanting or injecting live stem cells, differentiated or not, into a patient, in order to replace or regenerate damaged cells or tissues (Fig 5).

\section{MESENCHYMAL STEM CELLS OF DECIDUOUS PULPS: WHAT THE DENTAL SURGEON NEEDS TO KNOW}

Adult stem cells are classified, according to their origin, into hematopoietic and mesenchymal (Fig 6). Stem cells of hematopoietic origin are able to differentiate into specialized cells of white and red blood lines, while mesenchymal cells are able to differentiate into specialized cells that form hard tissues and organs, such as bones, cartilages, muscles, nerves, among others (Fig 6).

The stem cells present in the dental pulps are classified as mesenchymal, due to their ectomesenchymal embryonic origin, which gives them the ability to differentiate into a large number of specialized cells in the human body, such as bone, cartilage, muscle, neuronal cells, cardiac, pancreatic, among others. The youthfulness of these stem cells present in the pulps of deciduous teeth that will be lost and replaced 

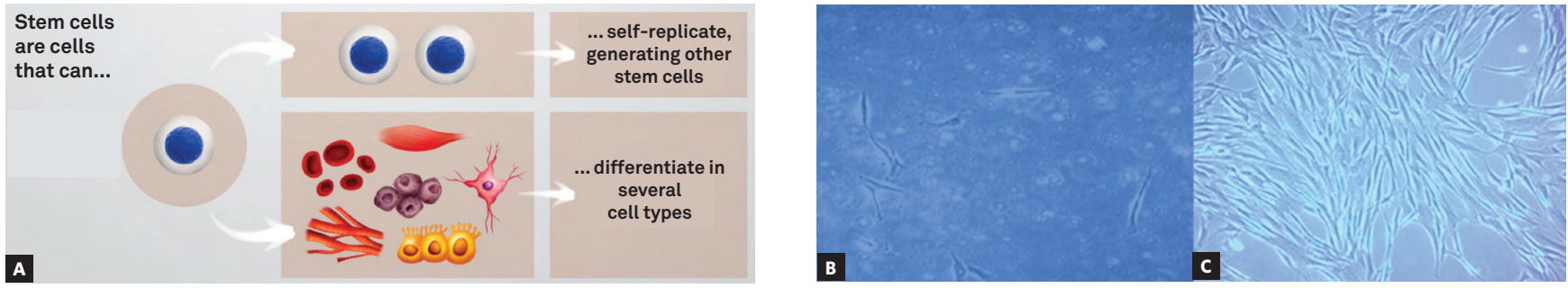

\section{As for classification, they can be:}
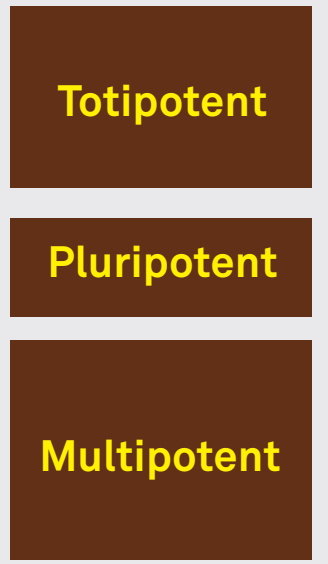

They differentiate in all $\mathbf{2 1 6}$ tissues that make up the human body, including the placenta and embryonic attachments. They are found in embryos in the early stages of cell division, which corresponds to three or four days of life.

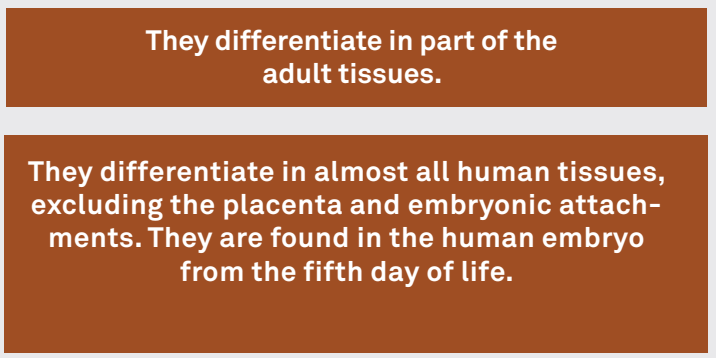

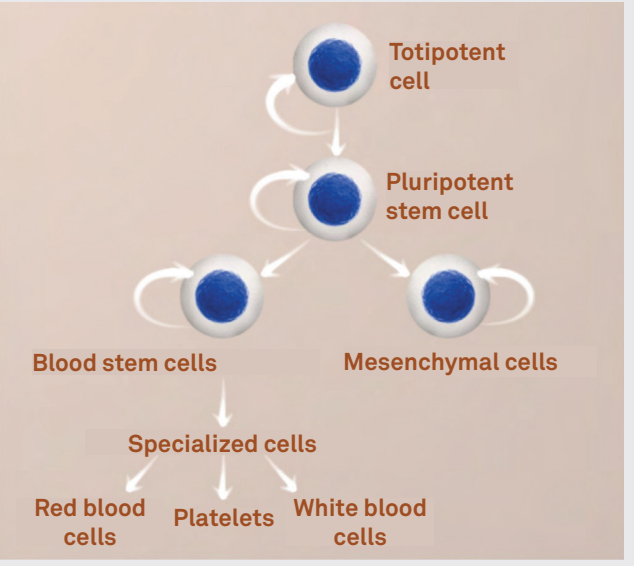
cells

\section{As for the origin, they can be:}

\section{EMBRYONIC}

They can only be found in human embryos and are classified as totipotent or pluripotent, given their high differentiation power.

\section{ADULTS}

They come from the human tissue already formed. They can be obtained from different adult tissues, such as bone marrow, liver, blood, adipose tissue, pulp of deciduous tooth, etc.

D

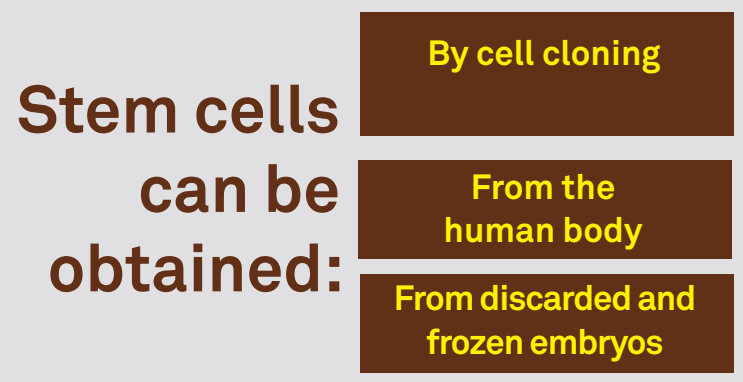
Cell manipulation technique capable of producing embryonic stem cells from the transfer of the already differentiated cell nucleus, from an adult or an embryo, to a enucleated ovum.

As explained, they are produced in some tissues of the body, but have limitations as to the differentiation in those same tissues.

\section{In assisted reproduction clinics.}

\section{The differences between them:}

Basically, there are two types of stem cells: those extracted from mature tissues of adults and children, and those extracted from embryos. In the case of those extracted from mature tissues, such as the umbilical cord, deciduous tooth or bone marrow, they are more specialized and give rise marrow, they are more specialized and give rise to only a few tissues in the body. Embryonic stem cells, on the other hand, have the potential to form any tissue in the body. That is the reason why this cell type is so targeted in scientific studies. The problem is that, in contrast to this versatility, embryonic stem cells can form tumors when applied in therapies, in addition to their potential for plied in therapies, in addition to their potential for the patient himself. Roberto Fanganiello, consultant at R-Crio and PhD in Genetics at the Bioscience Institute of University of SãoPaulo, explains that "[...] how stem cells collected from the pulp of the deciduous tooth are not embryonic, but adult stem cells, they are out of the boundaries of ethical or religious discussions."

E

Figure 1 - A) Stem cells are called nonspecific, and therefore have a great capacity for multiplication and differentiation. B) Image obtained by optical microscopy (10X), in which the presence of mesenchymal stem cells isolated from a deciduous dental pulp (4 days of culture) can be observed. C) Image obtained by optical microscopy (10X), in which the presence of isolated and expanded mesenchymal stem cells can be observed in the laboratory (12 days of culture, in confluence). D) Classification of stem cells according to their potential for differentiation and origin. E) Ways to obtain stem cells and differences between adult and embryonic stem cells. 


\section{A FACTORY OF AUTISTIC NEURONS}

The USP team employed, in an unprecedented way in Brazil, cell reprogramming techniques that won the 2012 Nobel Prize for Medicine.

\section{ONE NAME, SEVERAL DISEASES}

The so-called autism spectrum disorders (ASD) are a number of different disorders that involve symptoms such as difficulty in social interaction, communication problems and repetitive behaviors. These signs usually appear in the first years of life. Environmental and genetic factors are believed to be among their causes.

\section{Changes in more than} 300 genes are associated with ASD

04 AN AUTISTIC BRAIN IN FUNCTION The newly formed neurons carry the genetic information of the patient with autism. Scientists can study how they work, how they communicate and test medicines.

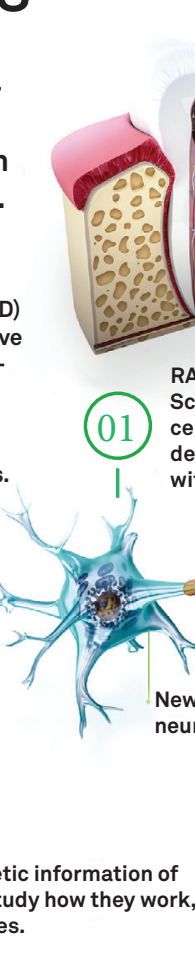

RAW MATERIAL COLLECTION Scientists extracted stem cells from the pulp of the deciduous tooth of patients with autism

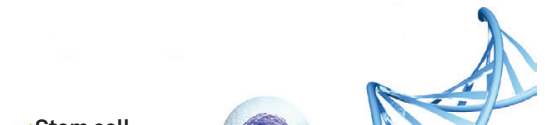

Figure 2 - Infogram based on the article by Griesi-Oliveira et al..$^{12}$

by permanent dentition, approximately between 6 and 12 years of age, added to their expressive capacity for multiplication and plasticity in the laboratory, in addition to the high immunomodulatory potential, make this model stand out from other existing sources of mesenchymal stem cells (Fig 7).

The performance of the dental surgeon is essential as the homologator of this applied science, as responsible for monitoring the child and choosing the best tooth for performing the collection. The promotion and maintenance of oral health since childhood is a decisive step towards the viability of the pulp stem cell cryopreservation process. The dental unit chosen may be deciduous in the process of exfoliation, with $1 / 3$ of the root volume remaining (the presence of the underlying permanent must be confirmed, with $2 / 3$ of rhizogenesis completed) or a third molar in the process of rhizogenesis, so that the entire process of isolation, multiplication and validation of the stem cells to be cryopreserved is favored, in suitable conditions, for autologous use in advanced therapies, when and if necessary (Fig 8).
Stem cells from dental pulps express osteogenic markers and respond to many growth factors for osteo-odontogenic differentiation, ${ }^{17-21}$ and also multiply very easily and with quality in the laboratory.

There are many applications and potentials for the use of these stem cells, which go far beyond the boundaries of Dentistry itself. For Dentistry, specifically, the osteogenic potential and the ability to regenerate complex tissues - such as the pulp, periodontal ligament and the tooth itself - give the dentist new and powerful tools, which need to be presented to society in a responsible manner.

Cell Processing Centers fulfill the role of promoting the proper treatment and storage of these stem cells, following the internationally established protocols of good practice, so that they can be used when and if necessary, in autologous or allogeneic form, in line with current regulations established by the competent regulatory agents.

In Brazil, regulatory advances regarding the so-called advanced therapies, that make use of stem cells or factors obtained from these, have been happening more and more rapidly and consistently. The resolutions published 


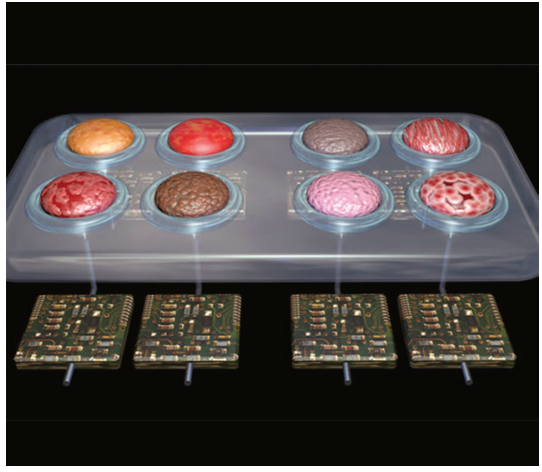

Figure 3 - Microfluidics: technology that allows creating organs on chips. Source: Bombaldi, ${ }^{13} 2019$.

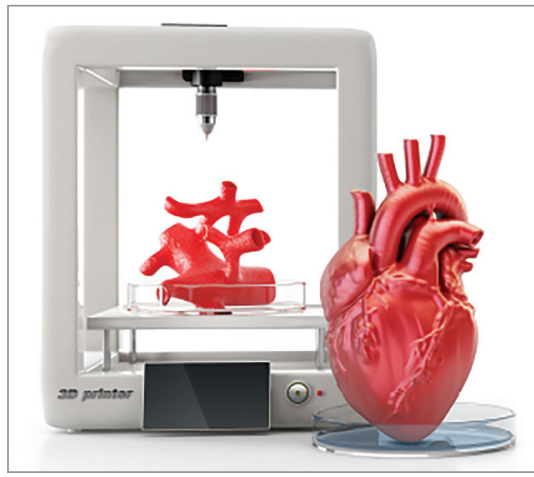

Figure 4 - Generation of organs in the laboratory

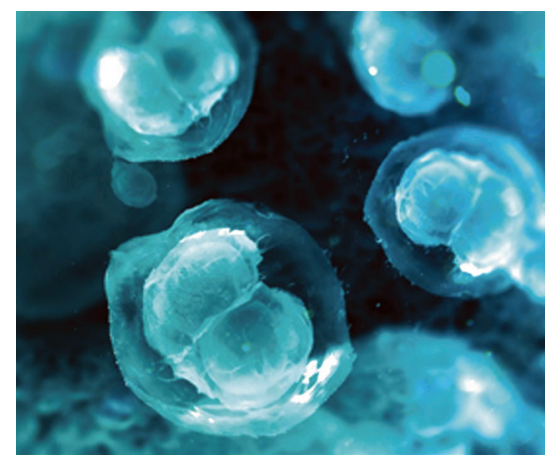

Figure 5 - Stem cells in cell therapy.

\begin{abstract}
HEMATOPOIETIC ADULTS

They are multipotent, that is, they have the potential to differentiate into any hematopoietic cell and can, in the long run, generate hematopoietic stem cells. They are located in the bone They are located in the bone
marrow, in the peripheral blood, in some organs such as the spleen and liver, in the umbilical cord blood and in the placenta.
\end{abstract}

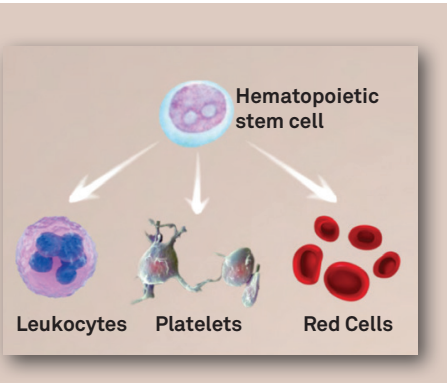

\section{MESENCHYMAL ADULTS}

They are a rare population of multipotent stem cells, which have the ability to differentiate into various tissues, such as bone, fat, cartilage, tendons, neuronal tissue, muscle, among others. Interest in this cell type has grown exponentially in recent years, due to its great potential for use in the regeneration of injured tissues use in the regeneration of injured tissues
and organs, as well as its great ability to modulate the immune response.

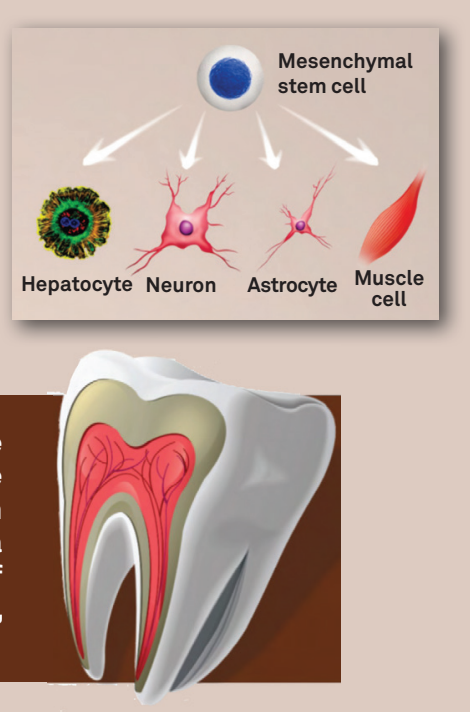

Figure 6 - Comparative illustration between adult hematopoietic and mesenchymal stem cells.

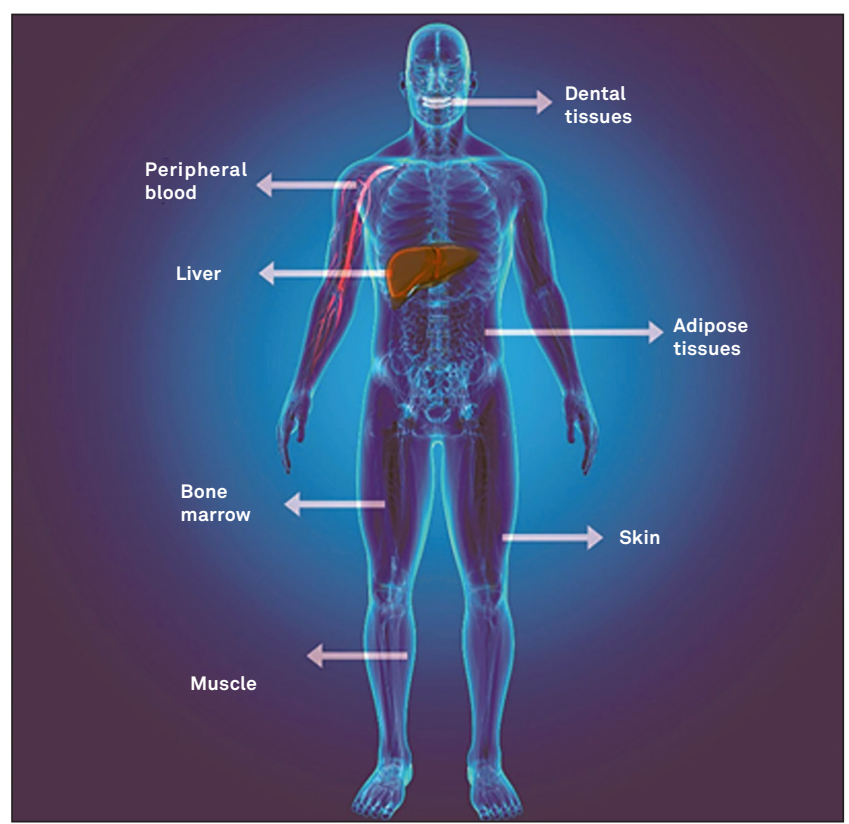

Figure 7 - Sources of mesenchymal stem cells.

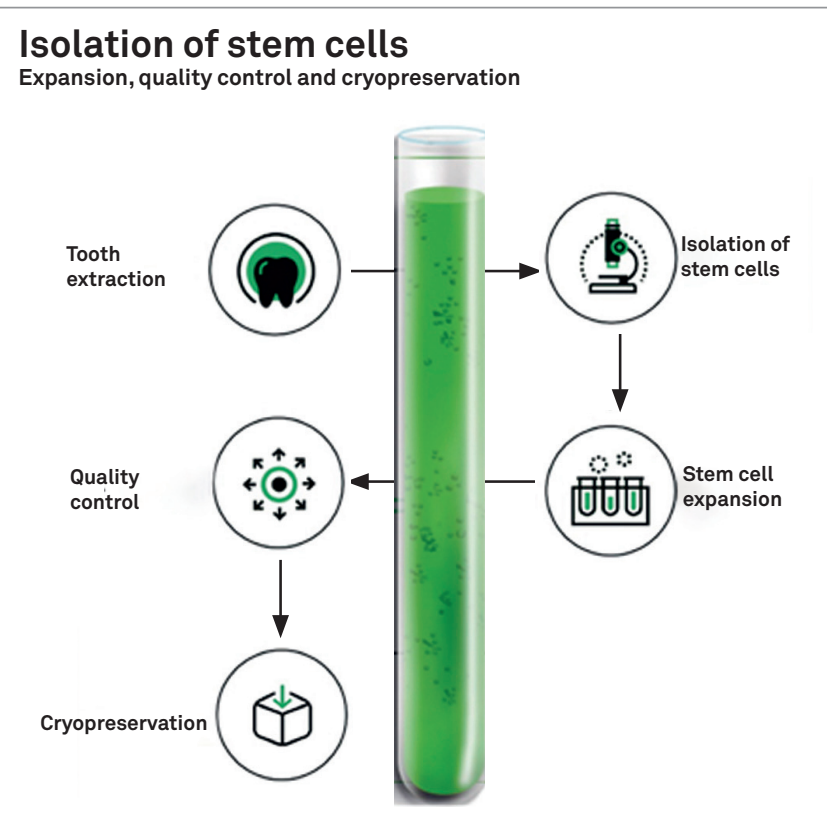

Figure 8 - Infographic with sequence of events for cell cryopreservation. 


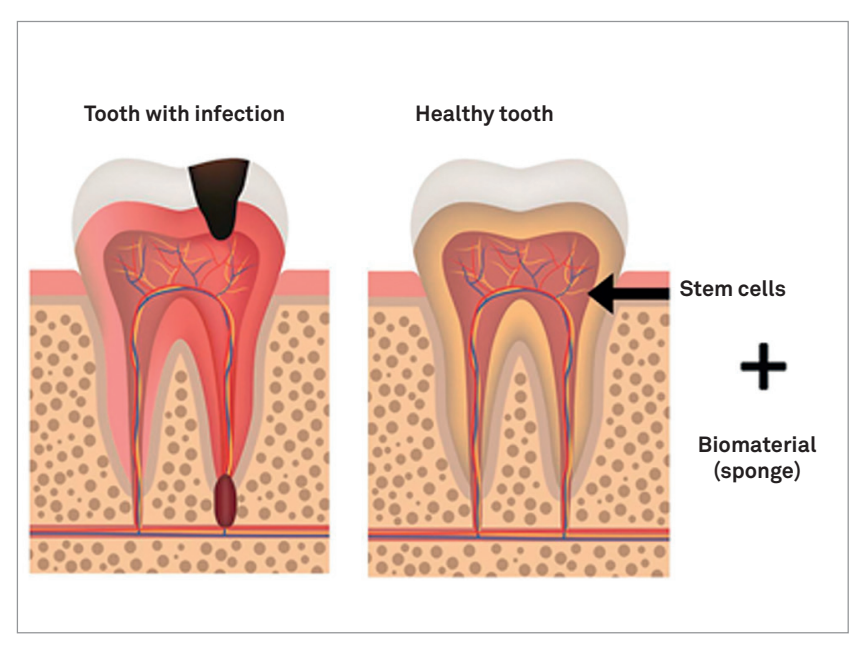

Figure 9 - Illustration of pulp regeneration.

by ANVISA (214/2018 22 - Good Practices in Human Cells for Therapeutic Use and Clinical Research, and 260/2018 ${ }^{23}$ - Rules for Conducting Clinical Trials with Advanced Investigational Therapy Product in Brazil), are an important demonstration of the environment favorable to the solid development of effectively innovative and transforming therapeutic protocols.

Cell Therapy brings the proposal to effectively and integrally regenerate tissues or organs morphologically, structurally and functionally damaged. Adult stem cells are presented as an important instrument, capable of leading and acting in this process in a decisive way. Countless basic and applied researches have been carried out all over the world, in order to prove the safety, efficacy, reproducibility, advantages and accessibility for the use of adult stem cells in Regenerative Medicine and Dentistry. ${ }^{24}$

\section{POSSIBLE CLINICAL APPLICATIONS OF MES- ENCHYMAL STEM CELLS IN DENTISTRY}

\section{Regeneration of pulp tissue}

In Brazil, in 2015, a group from the Faculty of Dentistry of the University of São Paulo (USP) presented, in a preclinical study in rats, a complete regeneration of the pulp tissue after 28 days of the pulpectomy and inoculation of autologous stem cells at the site. ${ }^{34}$ In 2017, Nakashima et $a 1 .{ }^{25}$ carried out the first clinical study with the purpose of evaluating the regenerative potential of pulp stem cells in pulp tissues affected by pulpitis, through autologous transplants. In this study, five patients diagnosed with irreversible pulpitis were submitted to endodontic treatment and then treated with autologous stem cells, with follow-up for 24 weeks. Pulp stem cells were associated with specific SDF1 factors (Factor 1 derived from stromal cells) in a collagen framework, since, according to the authors, the Regenerative Medicine triad - composed of progenitor cells, growth / migration factors and a framework - is essential for the "ideal" regenerative process to happen. After four weeks, they were able to verify a robust regenerative response, through electric pulp testing (EPT). At 24 weeks, through magnetic resonance imaging and computed tomography, they were able to observe the presence of regenerated pulp tissue and formation of functional dentin (Fig 9).

\section{Expanding the limits of orthodontic movement}

There are several factors that limit the extent of orthodontic movement, ${ }^{26}$ among which we can highlight the bone envelope, which is influenced by the pressure exerted by the adjacent soft tissues, neuromuscular forces and levels of periodontal insertion. Orthodontic movement is achieved by remodeling of the adjacent periodontal ligament in response to the load imposed from its constriction in the region influenced by the action of compressive orthodontic loads. ${ }^{27}$ Osteoclasts from hematopoietic stem cells ${ }^{28}$ are recruited to act directly in the bone remodeling process, accelerating the orthodontic movement.

The influence on orthodontic movement speed in relation to the expression of type- 1 collagen by stem cells from the adjacent periodontal ligament was demonstrated, based on a study carried out in rats. ${ }^{29}$ The authors observed the suppression of local type-1 collagen, by stem cells of the periodontal ligament, during the application of orthodontic load, and an increase in local expression after the removal of this load.

The use of stem cells can then represent an important window of opportunity for the bone remodeling process determined by the applied orthodontic forces to happen more quickly and predictably ${ }^{27,29}$ (Fig 10).

The tissue bioengineering strategy aimed at regenerating and/or increasing the bone ridge using mesenchymal stem cells from deciduous pulps associated with a biomaterial (framework) with osseoconductive, osseoinductive and bioactive properties is an excellent option to be considered in conditions ranging from the adequacy of the bone rim for orthodontics, to more extensive procedures aimed at orthopedics, 


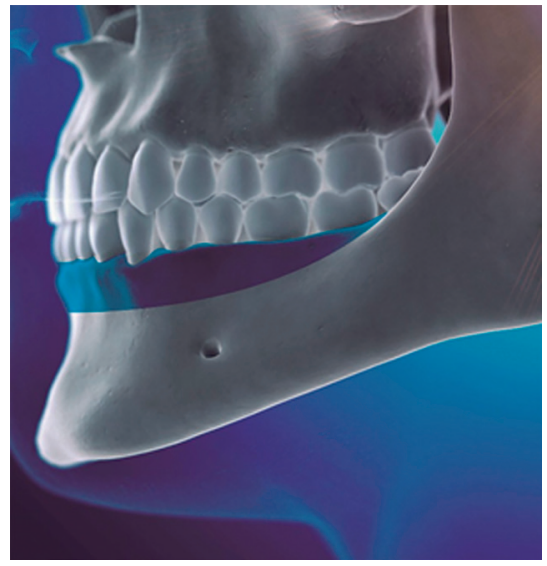

Figure 10 - Expansion of orthodontic movement limits.

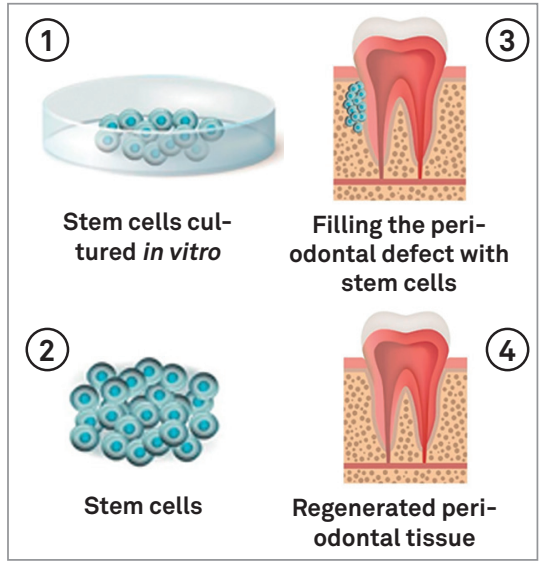

Figure 11 - Mesenchymal stem cells for periodontal regeneration.

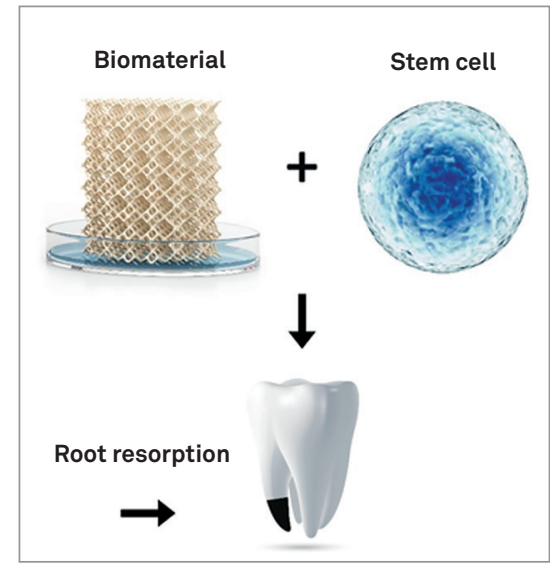

Figure 12 - Mesenchymal stem cells undergoing root regeneration (external resorption). such as dentofacial anomalies (cleft lip and palate), temporomandibular disorders, osteogenic distractions and maxillary expansions.

\section{Periodontal regeneration}

The periodontal phenotype must be considered with great attention in orthodontic planning, as cases of fenestration or gingival recession as a result of inappropriate orthodontic movement are not uncommon. However, once the framework is established, Guided Tissue Regeneration (GTR) techniques are a way to minimize the damage caused by the defect (Fig 11). Several authors have suggested that the path through GTR may have its results greatly improved if stem cells are associated with the process. Stem cells from the periodontal ligament have been especially considered in animal model ${ }^{30,31}$ and have been shown to be able to form specific periodontal structures when implanted in ectopic sites. ${ }^{32}$

\section{External root resorption}

This is a complication that often results from orthodontic treatments, and leads to loss of cementum and root dentin. The cementogenic potential of stem cells from the periodontal ligament and pericoronary follicle was investigated, considering that the cells that form the cementum are derived from these stem cells. ${ }^{33}$ The authors observed that stem cells from the periodontal ligament isolated by enzymatic digestion had special characteristics for cementogenesis. They were able to form, in vivo, a tissue similar to cell cementum, containing cells positive for osteocalcin. The other samples, on the other hand, formed materials similar to an acellular cemen- tum. Considering that the defect in the root cementum must be regenerated from the deposition of new cell cementum, the use of stem cells from the periodontal ligament isolated by enzymatic digestion may constitute a path to be followed in therapeutic attempts for regeneration in cases of external resorption root (Fig 12).

\section{FINAL CONSIDERATIONS}

The use of adult mesenchymal stem cells has been consolidated in the scientific and clinical communities, as an important tool for Regenerative Medicine and Dentistry. Therefore, it is necessary that applied research be strongly promoted, so that we have, in a short period of time, therapeutic possibilities increasingly efficient, safe, predictable and accessible to society without distinction. Clinicians face the challenge of disseminating information based on scientific evidence to the whole of society, giving the real dimension to this very important science. Dental surgeons are the only professionals qualified to choose and remove dental units for the purpose of cryopreservation of dental pulp stem cells. This exclusivity places Dentistry in a prominent position among the scientific community. Cell Processing Centers must continue to fulfill their important role of caring for and providing stem cells in conditions suitable for use in properly regulated research and advanced therapies. Finally, the competent regulatory entities must establish guidelines for good practices applied to laboratories, hospitals, clinics, therapy centers and professionals, while the Dentistry and Medicine Councils must coordinate, through the constitution of competent technical committees, the approval of the various possibilities of cell therapies that are 
described, proven and registered, in accordance with the international recommendations proposed by the main organized societies, such as the International Society for Cell and Gene Therapy (ISCT) and the International Society for Stem Cell Research (ISSCR).

\section{Acknowledgement}

The authors would like to thank the scientific and marketing committees of R-Crio Criogenia S.A., for their contribution to the production of content and images.

\section{REFERENCES}

1. United Nations. Data from Population Division of the Department of Economic and Social Affairs of the United Nations Secretariat (2007). World Populations Prospects: The 2006 Revision, Highlight. New York: United Nations, National Center for Health Statistics; 2009

2. World Health Organization. Data form WHO (2009). World Health Statistics, 2009. Geneva, Switzerland: World Health Organization; 2009.

3. Till JE, McCulloch EA. A direct measurement of the radiation sensitivity of normal mouse bone marrow cells. Radiat Res. 1961 Feb;14:213-22.

4. Friedenstein AJ, Piatetzky-Shapiro I, Petrakova KV. Osteogenesis in transplants of bone marrow cells. J Embryol Exp Morphol. 1966 Dec;16(3):381-90.

5. Zuk PA, Zhu M, Ashjian P. De Ugarte DA, Huang JI, Mizuno H, et al. Human adipose tissue is a source of multipotent stem cells. Mol Biol Cell. 2002 Dec;13(12):4279-95.

6. Wada MR, Inagawa-Ogashiwa M, Shimizu S, Yasumoto S, Hashimoto N. Generation of different fates from multipotent muscle stem cells. Development. 2002 June:129(12):2987-95

7. Bueno DF, Kerkis I, Costa AM, Martins MT, Kobayashi GS, Zucconi E, et al. New source of muscle-derived stem cells with potential for alveolar bone reconstruction in cleft lip and/or palate patients. Tissue Eng Part A. 2009 Feb:15(2):427-35

8. Gronthos S, Mankani M, Brahim J, Robey PG, Shi S. Postnatal human dental pulp stem cells (DPSCs) in vitro and in vivo. Proc Natl Acad Sci USA. 2000 Dec 5:97(25):13625-30

9. Toma JG, Akhavan M, Fernandes KJ, Barnabé-Heider F, Sadikot A, Kaplan DR, Miller FD. Isolation of multipotent adult stem cells from the dermis of mammalian skin. Nat Cell Biol. 2001 Sept;3(9):778-84.

10. Miura M, Gronthos S, Zhao M, Lu B, Fisher LW, Robey PG, et al. SHED: Stem cells from human exfoliated deciduous teeth. Proc Natl Acad Sci USA. 2003 May 13:100(10):5807-12.

11. R-Crio Criogenia S.A. R-Crio Células-tronco, 2020. Página inicial. Available from: <www.r-crio.com>. Acesso em 20 de maio de 2020

12. Griesi-Oliveira K, Suzuki AM, Alves AY, Mafra ACCN, Yamamoto GL, Ezquina $\mathrm{S}$, et al. Actin cytoskeleton dynamics in stem cells from autistic individuals. Sci Rep. 2018 July 24;8(1):11138.

13. Bombaldi F. A microfluídica envolve o uso de dispositivos minúsculos, mas promete avanços gigantes na área biomédica e para a indústria farmacêutica. Diversos estudos utilizam esta tecnologia para a criação de órgãos humanos em chips com o objetivo de utilizá-los para o teste de medicamentos e futuramente eliminar a necessidade de testes com animais. Blog Tudo Sobre Células-tronco, 2019. Available from <http:// tudosobrecelulastronco.com.br/microfluidica-orgaos-em-chips/>

14. Taylor DA, Sampaio LC, Ferdous Z, Gobin AS, Taite LJ. Decellularized matrices in regenerative medicine. Acta Biomater. 2018 July 1;74:74-89.

15. Lu T, Lin B, Kim J, Sullivan M, Tobita K, Salama G, et al. Repopulation of decellularized mouse heart with human induced pluripotent stem cell-derived cardiovascular progenitor cells. Nature Communications. 2013:4; Article 2307

16. Gershlak JR, Hernandez S, Fontana G, Perreault LR, Hansen KJ, Larson SA, et al. Crossing kingdoms: Using decellularized plants as perfusable tissue engineering scaffolds. Biomaterials. 2017 May;125:13-22.

17. Hanks CT, Sun ZL, Fang DN, Edwards CA, Wataha JC, Ritchie HH, et al. Cloned $3 T 6$ cell line from CD-1 mouse fetal molar dental papillae. Connect Tissue Res. 1998:37(3-4):233-49

18. Unda FJ, Martín A, Hilario E, Bègue-Kirn C, Ruch JV, Aréchaga J. Dissection of the odontoblast differentiation process in vitro by a combination of FGF1, FGF2, and TGFbeta1. Dev Dyn. 2000 July;218(3):480-9.

19. Ueno A, Kitase Y, Moriyama K, Inoue H. MC3T3-E1-conditioned mediuminduced mineralization by clonal rat dental pulp cells. Matrix Biol. 2001 Sept:20(5-6):347-55.
20. Fanganiello R, Ishiy F, Kobayashi GS, Alvizi L, Sunaga DY, Passos-Bueno MR. Increased in vitro osteopotential in SHED associated with higher IGF2 expression when compared with hASCs. Stem Cell Rev Rep. 2015 Aug:11(4):635-44

21. Ishiy FAA, Fanganiello RD, Kobayashi GS, Kague E, Kuriki PS, Passos-Bueno MR. CD 105 is regulated by hsa-miR-1287 and its expression is inversely correlated with osteopotential in SHED. Bone. 2018 Jan;106:112-20.

22. Brasil. Ministério da Saúde. Agência Nacional de Vigilância Sanitária. Diretoria Colegiada. Resolução da Diretoria Colegiada no 214, de 07 de fevereiro de 2018 Boas Práticas em Células Humanas para Uso Terapêutico e Pesquisa Clínica. Diário Oficial da União. 2018 Fev 22;(36).

23. Brasil. Ministério da Saúde. Agência Nacional de Vigilância Sanitária. Diretoria Colegiada. Resolução da Diretoria Colegiada no 260, de 21 de dezembro de 2018. Regras para a realização de ensaios clínicos com produto de terapia avançada investigacional no Brasil. Diário Oficial da União. 2018 Dez 21;(249).

24. US Department of Health \& Human Services. Website NIH National Institute of Health, 2020. Research and Training. Available from: <https://www.nih.gov> Access in: May 20, 2020.

25. Nakashima M, Iohara K, Murakami M, Nakamura H, Sato Y, Ariji Y, Matsushita K. Pulp regeneration by transplantation of dental pulp stem cells in pulpitis: a pilot clinical study. Stem Cell Res Ther. 2017 Mar 9;8(1):61.

26. Safari S, Mahdian A, Motamedian SR. Applications of stem cells in orthodontics and dentofacial orthopedics: Current trends and future perspectives. World J Stem Cells. 2018 June 26;10(6):66-77.

27. Masella RS, Meister M. Current concepts in the biology of orthodontic tooth movement. Am J Orthod Dentofacial Orthop. 2006 Apr:129(4):458-68.

28. Miyamoto T, Suda T. Differentiation and function of osteoclasts. Keio J Med. 2003 Mar;52(1):1-7.

29. Feng L, Yang R, Liu D, Wang X, Song Y, Cao H, et al. PDL Progenitor-mediated PDL recovery contributes to orthodontic relapse. J Dent Res. 2016;95(9):1049-56.

30. Ding G, Liu Y, Wang W, Wei F, Liu D, Fan Z, et al. Allogeneic periodontal ligament stem cell therapy for periodontitis in swine. Stem Cells. 2010 Oct;28(10):1829-38.

31. Wei F, Qu C, Song T, Song T, Ding G, Fan Z, Liu D, et al. Vitamin C treatment promotes mesenchymal stem cell sheet formation and tissue regeneration by elevating telomerase activity. J Cell Physiol. 2012 Sept:227(9):3216-24.

32. Seo BM, Miura M, Gronthos S, Bartold PM, Batouli S, Brahim J, et al. Investigation of multipotent postnatal stem cells from human periodontal ligament. Lancet. 2004 July 10-16:364(9429):149-55

33. Shinagawa-Ohama R, Mochizuki M, Tamaki Y, Suda N, Nakahara T. Heterogeneous human periodontal ligament- committed progenitor and stem cell populations exhibit a unique cementogenic property under in vitro and in vivo conditions. Stem Cells Dev. 2017:26(9):632-45

34. Bernardo J. Faculdade de Odontologia consegue reconstruir polpa dentária de ratos com células-tronco [online]. Agência Universitária de Notícias (AUN). 14/08/2015:48(75) [Access 2020 july 13). Available from: http://www.usp.br/aunantigo/exibir?id $=6995 \&$ ed $=1225 \& f=16$.

\section{Authors' contribution (ORCID $\left.{ }^{(i)}\right)$}

José Ferreira (JF): 0000-0002-5192-5623

Anna Paula Greck (APG): 0000-0003-0772-0572

Conception or design of the study: APG, JF. Data acquisition, analysis or interpretation: JF. Writing the article: APG, JF. Critical revision of the article: APG, JF. Final approval of the article: APG. Bibliographic references: JF. Overall responsibility: APG. 